\title{
Exogenous L-proline improved Rhodosporidium toruloides lipid production on crude glycerol
}

Rasool Kamal ${ }^{1,3}$, Yuxue Liu ${ }^{1,3}$, Qiang Li ${ }^{1,3}$, Qitian Huang ${ }^{1,2}$, Qian Wang ${ }^{1,2}$, Xue Yu ${ }^{1,2}$ and Zongbao Kent Zhao ${ }^{1,2^{*}}$ (1)

\begin{abstract}
Background: Crude glycerol as a promising feedstock for microbial lipid production contains several impurities that make it toxic stress inducer at high amount. Under stress conditions, microorganisms can accumulate L-proline as a safeguard. Herein, L-proline was assessed as an anti-stress agent in crude glycerol media.

Results: Crude glycerol was converted to microbial lipids by the oleaginous yeast Rhodosporidium toruloides CGMCC 2.1389 in a two-staged culture mode. The media was supplied with exogenous L-proline to improve lipid production efficiency in high crude glycerol stress. An optimal amount of $0.5 \mathrm{~g} / \mathrm{L}$ L-proline increased lipid titer and lipid yield by $34 \%$ and $28 \%$, respectively. The lipid titer of $12.2 \mathrm{~g} / \mathrm{L}$ and lipid content of $64.5 \%$ with a highest lipid yield of $0.26 \mathrm{~g} / \mathrm{g}$ were achieved with L-proline addition, which were far higher than those of the control, i.e., lipid titer of $9.1 \mathrm{~g} / \mathrm{L}$, lipid content of $58 \%$ and lipid yield of $0.21 \mathrm{~g} / \mathrm{g}$. Similarly, L-proline also improved cell growth and glycerol consumption. Moreover, fatty acid compositional profiles of the lipid products was found suitable as a potential feedstock for biodiesel production.
\end{abstract}

Conclusion: Our study suggested that exogenous L-proline improved cell growth and lipid production on crude glycerol by $R$. toruloides. The fact that higher lipid yield as well as glycerol consumption indicated that L-proline might act as a potential anti-stress agent for the oleaginous yeast strain.

Keywords: Anti-stress agent, Crude glycerol, Microbial lipids, Rhodosporidium toruloides, Two- stage culture

\section{Background}

Biodiesel is a renewable alternative to fossil fuels [1]. Its global production has increased dramatically in the past decade [2]. Unlike fossil fuels, biodiesel is eco-friendly and non-toxic with less sulfur and carbon dioxide emissions [3]. However, biodiesel production generates about $10 \%$ crude glycerol as a by-product, which contains several impurities at the risk of disposal [4]. As a result, several European countries treat it as industrial wastewater

\footnotetext{
*Correspondence: zhaozb@dicp.ac.cn

1 Laboratory of Biotechnology, Dalian Institute of Chemical Physics, CAS,

457 Zhongshan Road, Dalian 116023, People's Republic of China

Full list of author information is available at the end of the article
}

[5]. For this reason, the conversion of crude glycerol to value-added products is essential [1].

The current biodiesel technology is based on plant oils and animal fats, but these resources are limited. The lipid produced by oleaginous microorganisms is known to be a novel feedstock for biodiesel production with similar fatty acids composition to that as plants oil [6]. Moreover, microbial lipid has several leads over plants oil including; free of weather and land use, have high productivity, short production cycle, and easy scalability [7]. Among others, the oleaginous yeasts are considered as potential lipid producers due to their higher growth rate, adaptation to diverse substrates, and higher lipid production yields. Until now, various organic substrates including waste cooking oils [8], different biomass derived sugars

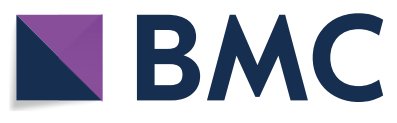

(C) The Author(s) 2020. This article is licensed under a Creative Commons Attribution 4.0 International License, which permits use, sharing, adaptation, distribution and reproduction in any medium or format, as long as you give appropriate credit to the original author(s) and the source, provide a link to the Creative Commons licence, and indicate if changes were made. The images or other third party material in this article are included in the article's Creative Commons licence, unless indicated otherwise in a credit line to the material. If material is not included in the article's Creative Commons licence and your intended use is not permitted by statutory regulation or exceeds the permitted use, you will need to obtain permission directly from the copyright holder. To view a copy of this licence, visit http://creativeco mmons.org/licenses/by/4.0/. The Creative Commons Public Domain Dedication waiver (http://creativecommons.org/publicdomain/ zero/1.0/) applies to the data made available in this article, unless otherwise stated in a credit line to the data. 
[9], amino acid-rich wastes [10], and industrially produced organic wastes [11], have been utilized for microbial lipid production. However, the high production cost of microbial lipid technology prevent its broader commercialization [12], where the fermentation processes and substrate costs are significant to lipid production [13]. Thereby, in sighting cost-effective raw materials for microbial lipid technology are in need.

Previously, crude glycerol has been utilized as a carbon source for valued microbial products like citric acid [14], biopolymers [15], 1,3-propanediol [16], succinic acid [17], and microbial lipid, however, the lipid yield remained lower [18]. Many microbes are unable to utilize it efficiently [19], due to the presence of methanol, salts, organic acids, and heavy metals etc., which induce toxicity at high level [20]. On the contrary, different organisms accumulate L-proline during hostile conditions. As a compatible solute, L-proline exhibits several in vitro functions [21]; it improves protein and membrane stabilization during freezing [22], elevated temperatures [23], dehydration [21], lowers the DNA melting temperature during salinity stress [24], increases proteins solubility [25], prevents proteins aggregation [26], scavenges reactive oxygen species (ROS) [27, 28], and prevents ROS mediated cell inhibition [29, 30]. Although, the exact mechanism for each function in vivo is unclear [21].

To efficiently convert the crude glycerol into microbial lipid, exogenous L-proline was added to the media to rescue the adverse effects of crude glycerol stress on the yeast strain. The effect of different L-proline and crude glycerol concentrations were evaluated on lipid production. Lipid were produced by Rhodosporidium toruloides AS 2.1389 in a two-stage culture mode under maintained media $\mathrm{pH}$ 5.5. Indeed, L-proline improved cell growth, lipid accumulation and lipid yield along with rapid glycerol consumption. Our finding concluded that exogenous L-proline improved overall lipid production efficiency of the strain.

\section{Results and discussion}

Time course of L-proline uptake, glycerol consumption and lipid production

The culture process was monitored to evaluate the effects of L-proline on the kinetics of lipid production in comparison to that with control. L-proline uptake was followed by instant analysis with IC until L-proline exhaustion.

Result indicated a quick gradual decrease in L-proline uptake, and the complete exhaustion occurred within the first $3 \mathrm{~h}$ of fermentation (Fig. 1a). The rapid L-proline uptake might was due to the initial stress conditions exerted by the crude glycerol which was indicated by lower growth on control, as well as least glycerol consumption in both media during initial $24 \mathrm{~h}$. However, a speedy glycerol consumption was observed after $24 \mathrm{~h}$, especially on L-proline added media (Fig. 1b). The same phenomena of glycerol consumption was reported previously [31]. Since, L-proline supported higher growth and lipid production throughout the fermentation. The cell mass of $18.9 \mathrm{~g} / \mathrm{L}$, lipid $12.2 \mathrm{~g} / \mathrm{L}$ and lipid content of $64.5 \%$ on L-proline added media were all significantly $(P<0.001)$ higher compared to those of control, i.e., $15.5 \mathrm{~g} / \mathrm{L}, 9.1 \mathrm{~g} / \mathrm{L}$ and $58.6 \%$, respectively (Fig. 1b-d).

Moreover, L-proline not only supported higher growth and lipid production, but also resulted in a highest lipid yield. Along with the higher glycerol consumption of $46.7 \mathrm{~g} / \mathrm{L}$, the lipid yield of $0.26 \mathrm{~g} / \mathrm{g}$ was apparently higher on L-proline added media than that of control i.e., $0.21 \mathrm{~g} / \mathrm{g}$. As per our knowledge, the achieved lipid yield was the highest among previous researches with crude glycerol as a substrate (Table 1). It is noteworthy that L-proline addition increased the yeast efficiency by $18 \%$, $25 \%$ and $16 \%$ in terms of cell mass, lipid and lipid yield, respectively. This demonstrated L-proline as a promising anti-stress agent for $R$. toruloides.

\section{The effects of initial media $\mathrm{pH}$ on lipid production}

Culture $\mathrm{pH}$ has significant effects on cell growth and product accumulation [32]. As $\mathrm{H}_{2} \mathrm{SO}_{4}$ and $\mathrm{KOH}$ (or $\mathrm{NaOH}$ ) are commonly utilized for biodiesel preparation, the by-product crude glycerol may have different $\mathrm{pHs}$, which could be a problem to explore crude glycerol as a substrate for microbial conversion. Therefore, the effects of different initial pH 5.0, 5.5 and 6.0, respectively, were tested on $R$. toruloides lipid production in the presence of $0.5 \mathrm{~g} / \mathrm{L} \mathrm{L}$-proline, where the control had no L-proline. Note that the yeast initially produce organic acids [33], that might take the culture $\mathrm{pH}$ to lower ranges [34]. For the reason, the media was supplied with $100 \mathrm{mM}$ MES buffer to maintain the initially adjusted $\mathrm{pH}$.

Likely, the strain showed lower values on the control at all tested $\mathrm{pH}$ ranges. Although significantly lower $(P<0.05)$ cell mass and lipid were achieved on the control at $\mathrm{pH} 6.0$ compared to those of L-proline added media, the lipid and lipid content of $7.2 \mathrm{~g} / \mathrm{L}$ and $53 \%$, respectively, with highest cell mass of $13.7 \mathrm{~g} / \mathrm{L}$ were relatively higher at initial pH 5.5 among all controls (Fig. 2a). In contrast, there were no substantial differences in terms of cell mass and lipid titer on L-proline added media at all $\mathrm{pH}$ ranges, but the initial $\mathrm{pH} 5.5$ improved overall efficiency of the strain both on control and L-proline added media which was in line with our previous report [34]. At initial $\mathrm{pH} 5.5$, the cell mass reached the highest $14.3 \mathrm{~g} / \mathrm{L}$ along with $8.4 \mathrm{~g} / \mathrm{L}$ lipid and lipid contents of $58 \%$, with L-proline addition (Fig. 2a). Moreover, in addition with higher glycerol consumption, the lipid yield of $0.18 \mathrm{~g} / \mathrm{g}$ 

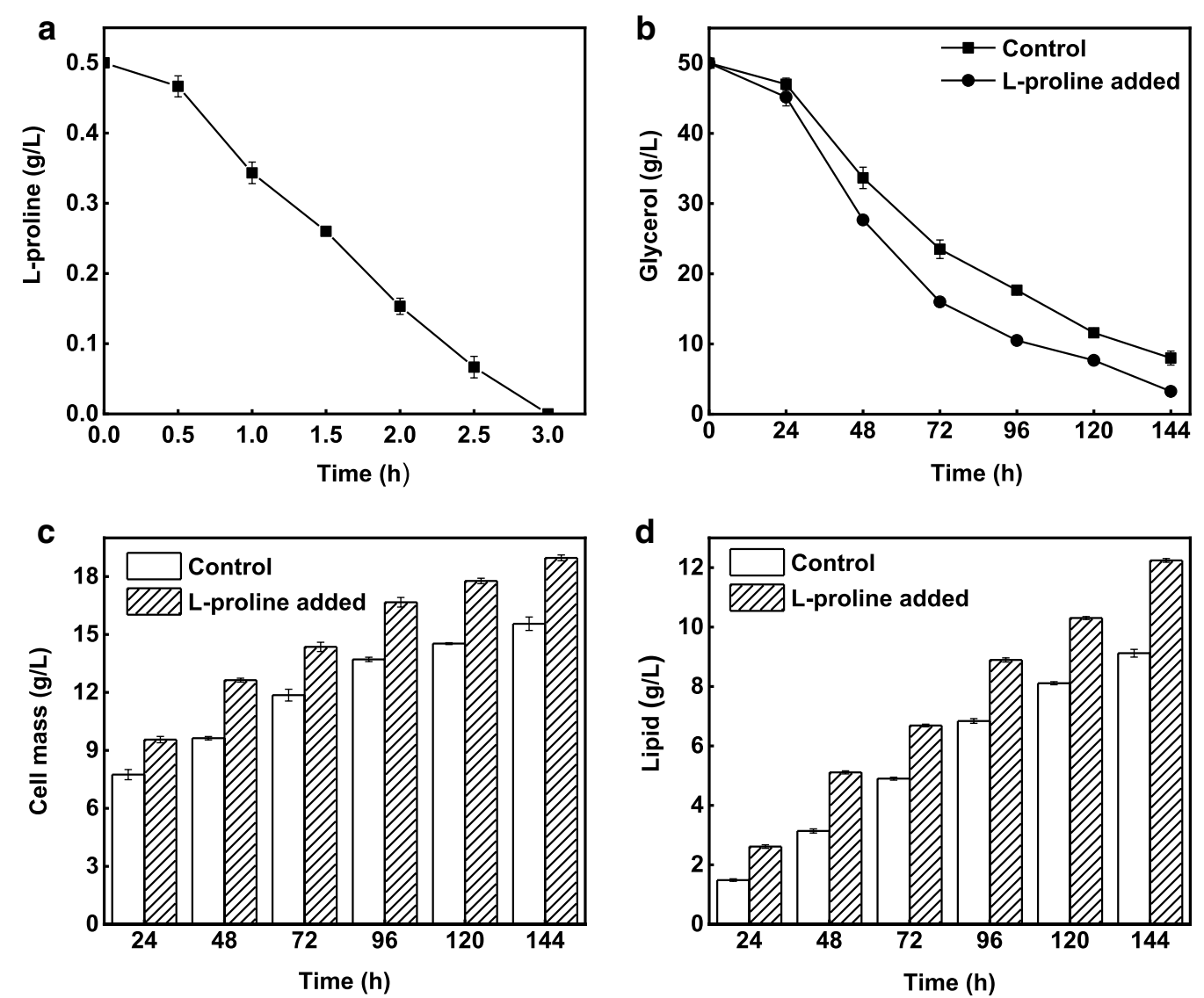

Fig. 1 Results of lipid production time course on crude glycerol. a L-proline uptake. b Glycerol consumption. c Cell mass production. $\mathbf{d}$ Lipid production. Culture was performed at $30^{\circ} \mathrm{C}$ and $200 \mathrm{rpm}$ for $144 \mathrm{~h}$

Table 1 Lipid production by oleaginous yeasts on glycerol as a carbon source

\begin{tabular}{|c|c|c|c|c|c|}
\hline Strain & Cell mass (g/L) & Lipid (g/L) & Lipid content (\%) & Lipid yield (g/g) & References \\
\hline R. toruloides ATCC 10788 & 08.0 & 02.5 & 31.7 & 0.07 & [44] \\
\hline R. toruloides AS2.1389 & 19.2 & 09.2 & 47.7 & 0.14 & {$[52]$} \\
\hline R. glutinis TISTR 5159 & 08.1 & 04.3 & 52.9 & 0.06 & [53] \\
\hline T. cutaneum & 17.4 & 05.6 & 32.2 & 0.17 & [54] \\
\hline T.fermentans & 16.0 & 05.2 & 32.4 & 0.16 & [54] \\
\hline R. toruloides $Y 4$ & 24.9 & 12.2 & 48.9 & 0.22 & [34] \\
\hline R. toruloides NRRL Y-27012 & 16.7 & 07.9 & 47.2 & 0.17 & {$[55]$} \\
\hline R. toruloides AS 2.1389 & 26.5 & 10.0 & 38.0 & 0.20 & {$[56]$} \\
\hline R. toruloides AS 2.1389 & 15.5 & 09.1 & 58.6 & 0.21 & This study ${ }^{a}$ \\
\hline R. toruloides AS 2.1389 & 18.9 & 12.2 & 64.5 & 0.26 & This study ${ }^{b}$ \\
\hline
\end{tabular}

a Crude glycerol media without L-proline

${ }^{b}$ Crude glycerol media with $0.5 \mathrm{~g} / \mathrm{L}$ L-proline

was the highest on L-proline added media at initial $\mathrm{pH}$ 5.5 (Fig. 2b).

Although there were no substantial differences in lipid production at all applied $\mathrm{pH}$ ranges, but higher lipid titer were achieved on all L-proline added media. These results suggested that the $R$. toruloides strain CGMCC 2.1389 has good capability to work on $\mathrm{pH}$ ranges between 5.0 and 6.0 . 

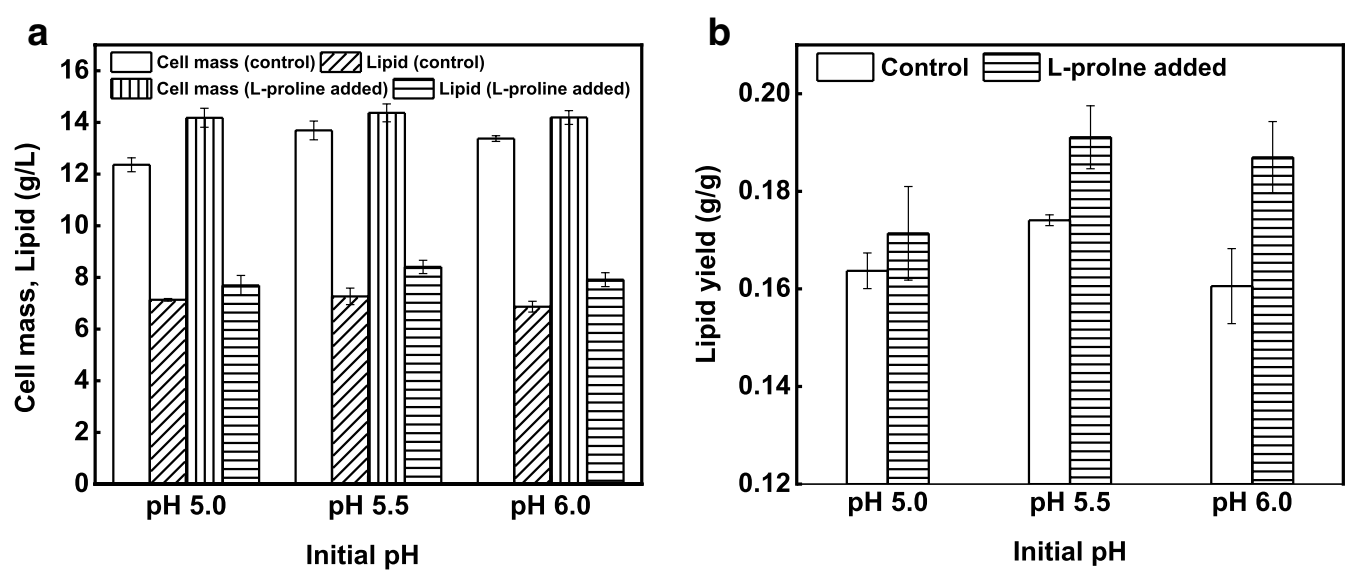

Fig. 2 Effects of initial pH on lipid production. a Cell mass and lipid production. b Lipid yield

\section{Effects of methanol and crude glycerol concentration on lipid production}

Methanol in crude glycerol comes from a transesterification reaction; however, depends on the separation process, varied concentration of methanol can be found in the aqueous phase [35]. As per previous reports, high contents of methanol in crude glycerol could inhibit cellular growth [36], and lipid production [37]. Therefore, methanol effects were tested on the yeast growth and lipid production in the presence of L-proline. The lipid production media was sterilized at $121{ }^{\circ} \mathrm{C}$ for $20 \mathrm{~min}$ together with $5 \mathrm{~g} / \mathrm{L}$ methanol $(\mathrm{G}+\mathrm{MeOH}, \mathrm{GP}+\mathrm{MeOH}$ : where "G" stand for control and "GP" stand for media with $0.5 \mathrm{~g} / \mathrm{L} \mathrm{L}$-proline), or the same amount of methanol was added to the media with syringe filters after sterilization (G-MeOH, GP-MeOH). Where "G \pm " stand for control and "GP \pm " stand for media with $0.5 \mathrm{~g} / \mathrm{L} \mathrm{L}$-proline. As methanol has about $64.7{ }^{\circ} \mathrm{C}$ boiling point, the sterilized media will have no methanol due to evaporation $[38,39]$.

Later on, no considerable differences were found in cell mass and lipid production in terms of methanol availability. The media supplemented with methanol after sterilization was with slightly higher growth and lipid production, which indicated that $5 \mathrm{~g} / \mathrm{L}$ methanol had no adverse effects on $R$. toruloides growth and lipid accumulation, but conversely improved the yeast efficiency. However, higher cell mass and lipid were achieved on L-proline added media in both conditions $(\mathrm{GP}+\mathrm{MeOH}$, $\mathrm{GP}-\mathrm{MeOH})$ compared to that with controls $(\mathrm{G}+\mathrm{MeOH}$, $\mathrm{G}-\mathrm{MeOH}$ ) (Fig. 3c). The $15.3 \mathrm{~g} / \mathrm{L}$ cell mass and $7.0 \mathrm{~g} / \mathrm{L}$ lipid were achieved on control while these were $17.8 \mathrm{~g} / \mathrm{L}$ and $9.2 \mathrm{~g} / \mathrm{L}$, respectively, on L-proline added media sterilized together with methanol. Hence, the control supplemented with methanol after sterilization was with $15.4 \mathrm{~g} / \mathrm{L}$ cell mass and $7.5 \mathrm{~g} / \mathrm{L}$ lipid compared those with
$17.5 \mathrm{~g} / \mathrm{L}$ and $9.3 \mathrm{~g} / \mathrm{L}$ on L-proline added media. In both conditions, the glycerol consumption was about $40 \mathrm{~g} / \mathrm{L}$ on both controls with the same lipid yields of about $0.18 \mathrm{~g} / \mathrm{g}$. Likewise, the same phenomena was observed with $\mathrm{L}$-proline addition where the glycerol consumption was above $46 \mathrm{~g} / \mathrm{L}$ and lipid yield of more than $0.21 \mathrm{~g} / \mathrm{g}$ (Fig. 3a). L-proline addition enhanced cell growth, lipid production, glycerol consumption, and lipid yield compared with control. Moreover, these results suggested that $5 \mathrm{~g} / \mathrm{L}(10 \% \mathrm{w} / \mathrm{w})$ methanol had no inhibitory effects on $R$. toruloides growth and lipid accumulation [35, 39], but further encouraged the yeast efficiency [34].

Since the high substrate concentration has adverse effects on yeast growth and lipid production due to high osmotic stress [14]. To further study the effects of wide ranges of methanol, salt and glycerol concentration on yeast efficiency in the presence of $0.5 \mathrm{~g} / \mathrm{L}$ exogenous L-proline, different glycerol concentrations; $50 \mathrm{~g} / \mathrm{L}$, $100 \mathrm{~g} / \mathrm{L}, 150 \mathrm{~g} / \mathrm{L}$, and $200 \mathrm{~g} / \mathrm{L}$ were used in the media. Note that, methanol and $\mathrm{K}_{2} \mathrm{SO}_{4}$ were used at $10 \% \mathrm{w} / \mathrm{w}$ each, therefore, with the increase in initial glycerol concentration, the concentrations of salt and methanol were also increased in the media.

Indeed, when the glycerol concentration exceeded $100 \mathrm{~g} / \mathrm{L}$, cell growth and lipid accumulation were affected, but compared to that with the control, higher cell mass and lipid were achieved on L-proline added media (Fig. 3d). Since, control with $50 \mathrm{~g} / \mathrm{L}$ glycerol resulted in $14.7 \mathrm{~g} / \mathrm{L}$ cell mass, $7.7 \mathrm{~g} / \mathrm{L}$ lipid and $0.18 \mathrm{~g} / \mathrm{g}$ lipid yield, whereas, these were $17.1 \mathrm{~g} / \mathrm{L}, 8.7 \mathrm{~g} / \mathrm{L}$, and $0.20 \mathrm{~g} / \mathrm{g}$, respectively, on L-proline added media (Fig. 3b, d). However, the highest cell mass of $17.4 \mathrm{~g} / \mathrm{L}$ and lipid of $9.8 \mathrm{~g} / \mathrm{L}$ were achieved on L-proline added media with $100 \mathrm{~g} / \mathrm{L}$ crude glycerol, while these were $15.9 \mathrm{~g} / \mathrm{L}, 8.1 \mathrm{~g} / \mathrm{L}$, respectively on control. Indicating that $100 \mathrm{~g} / \mathrm{L}$ glycerol favored the yeast efficiency, where the lipid yield of $0.21 \mathrm{~g} / \mathrm{g}$ also 

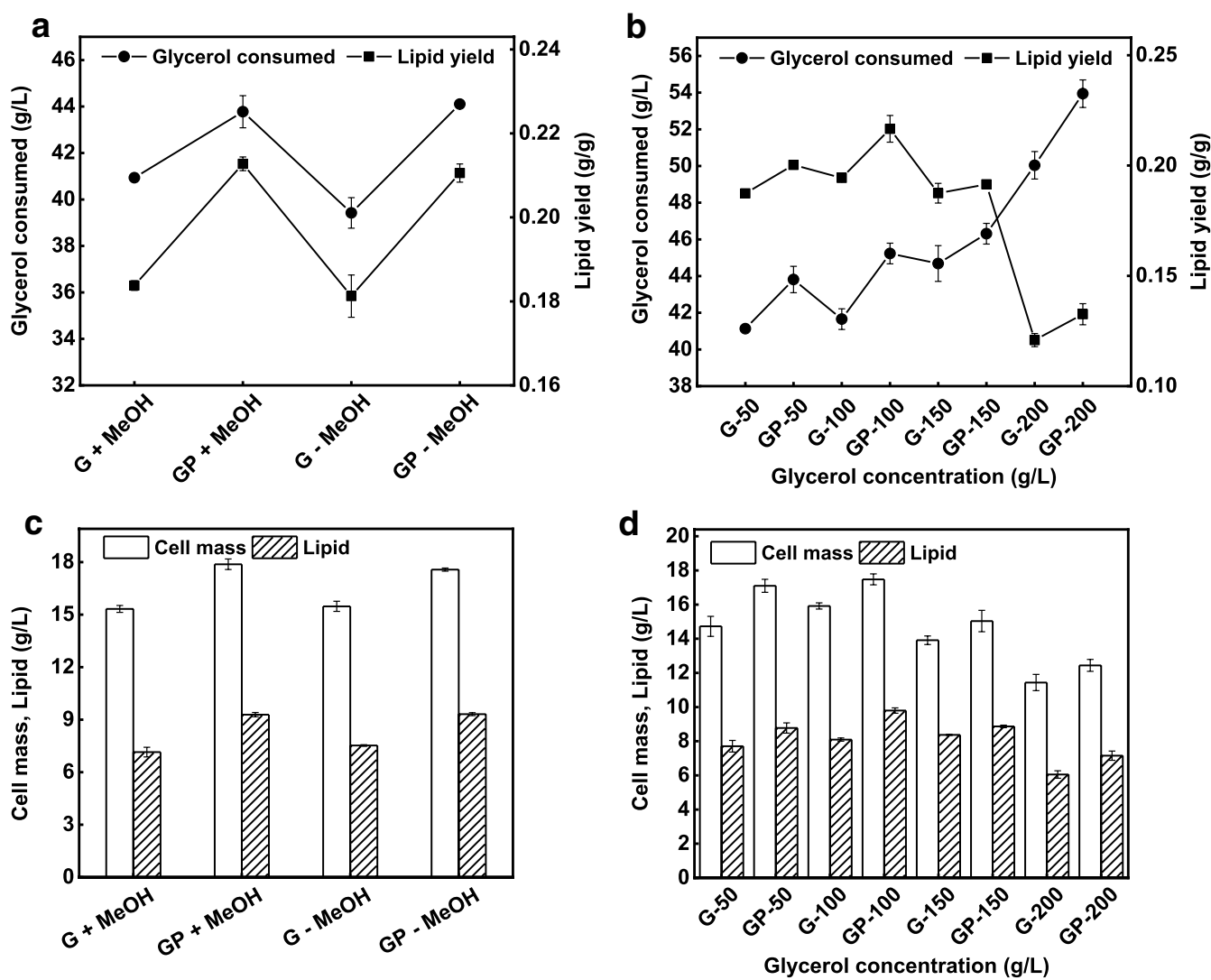

Fig. 3 Effects of methanol and crude glycerol on lipid production. a Glycerol consumption and lipid yield on glycerol media with and without methanol. $\mathbf{b}$ Glycerol consumption and lipid yield on different crude glycerol concentration. $\mathbf{c}$ Lipid production on crude glycerol media with and without methanol. d Lipid production on media with different crude glycerol concentration

reached the higher with L-proline addition compared to that with the control i.e., $0.19 \mathrm{~g} / \mathrm{g}$, respectively, (Fig. 3b). On the other hand, when the glycerol concentration further increased to $150 \mathrm{~g} / \mathrm{L}$, the cell mass and lipid were decreased. The control was with a cell mass of $13.8 \mathrm{~g} / \mathrm{L}$, lipid $8.3 \mathrm{~g} / \mathrm{L}$, with a lower lipid yield of $0.18 \mathrm{~g} / \mathrm{g}$ while these were higher on L-proline added media i.e., $15 \mathrm{~g} / \mathrm{L}$, $8.8 \mathrm{~g} / \mathrm{L}$ and $0.19 \mathrm{~g} / \mathrm{g}$, respectively. The decrease in cellular growth and lipid accumulation might was due to various factors; the media with the high amount of crude glycerol contained high amount of salt and methanol, which put adverse effects on cell growth and lipid accumulation [40]. It has been known that methanol could have some weak effects on microbial cell membrane fluidity, and thus methanol at $6.5 \mathrm{~g} / \mathrm{L}$ or higher concentrations inhibited cell growth [35, 41, 42]. Methanol has also been shown to inhibit docosahexaenoic acid production from crude glycerol by Schizochytrium limacinum [37]. Similarly, excess salts also generate osmotic pressures that have adverse effects on microbial cell growth [43] and product yield [44]. Likewise, high crude glycerol concentration in the media exerts high osmotic stress [14].
Moreover, the high glycerol concentration might lead to in low oxygen mixing due to high viscosity which resulted lower growth and lipid production, which is also indicated by further decrease in cell mass and lipid production when glycerol concentration increased to $200 \mathrm{~g} / \mathrm{L}$ (Fig. 3b, d).

These results indicated that below $100 \mathrm{~g} / \mathrm{L}$ crude glycerol was an optimum concentration for the yeast growth and lipid accumulation (Table 2, entry 3-8). However, the yeast showed higher growth and lipid production efficiency on L-proline added media which proves L-proline as a potential osmoprotectant $[45,46]$.

\section{Effects of L-proline level and supply time on lipid production}

Previous reports confirmed improved yeast tolerance to various inhibitors by enhancing L-proline biosynthesis $[45,46]$. However, the excess of $\mathrm{L}$-proline accumulation in the cytosol might also be toxic to yeast cells [47]. In order to find an optimum L-proline concentration, the media was supplied with different levels of $\mathrm{L}$-proline $\mathrm{g} / \mathrm{L}$; 0.0 (control), $0.25,0.5,0.725,1.0$, and 1.25 . 


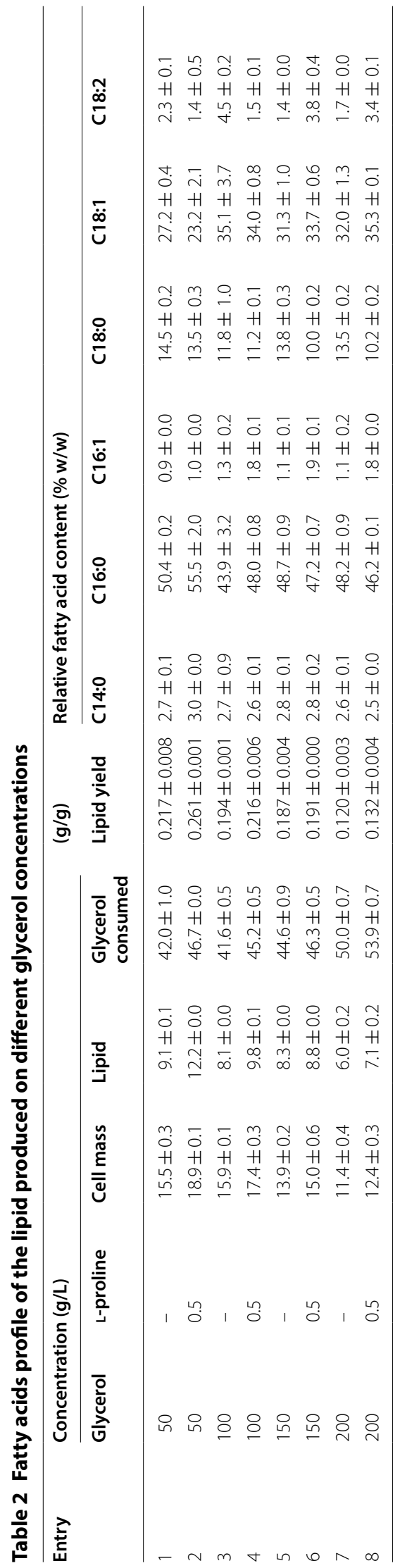



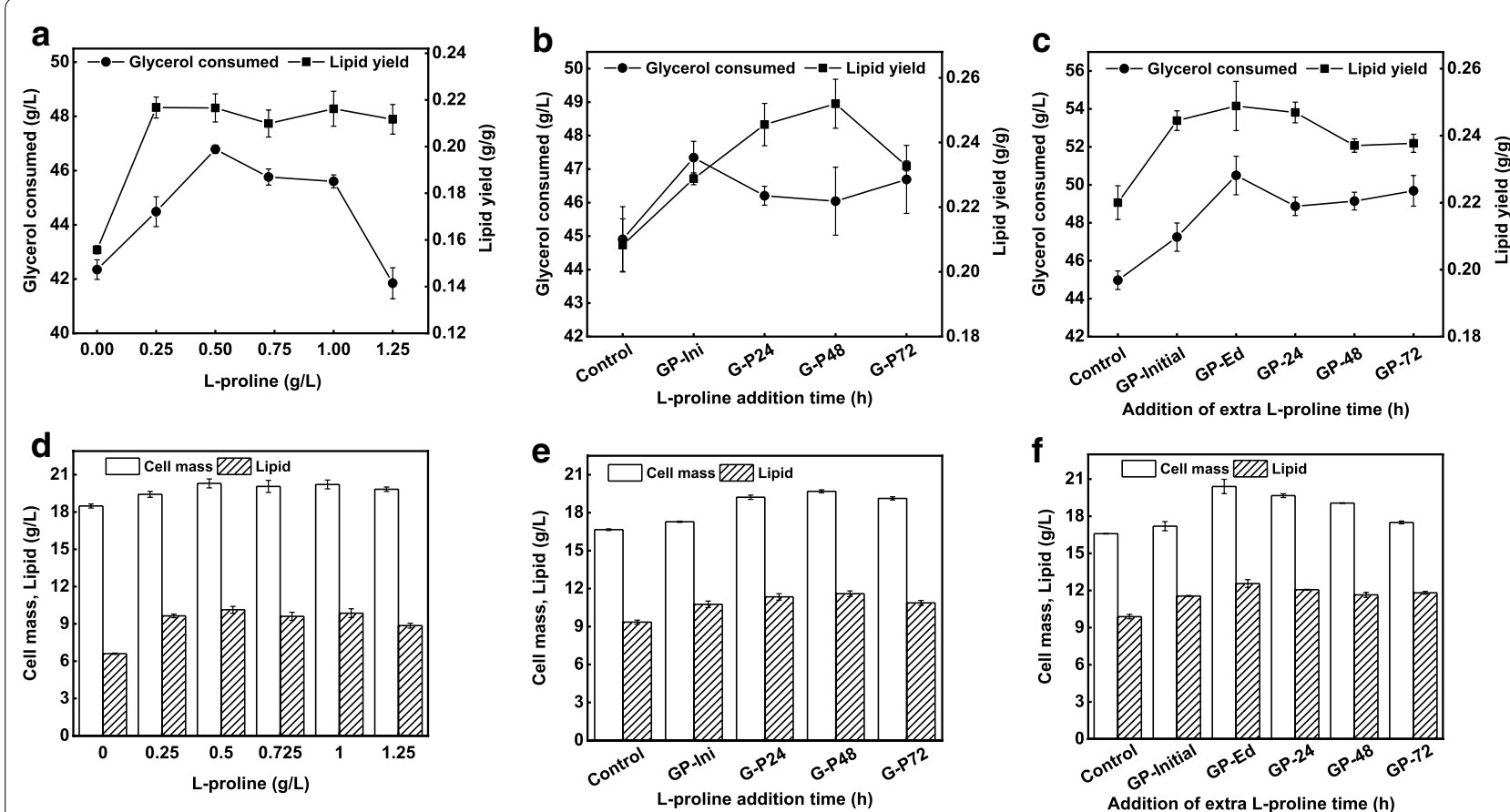

Fig. 4 Effects of L-proline on lipid production from crude glycerol. a Effects of different L-proline levels on glycerol consumption and lipid yield. b Effects of $0.5 \mathrm{~g} / \mathrm{L} \mathrm{L}$-proline addition after different time intervals on glycerol consumption and lipid yield. c Effects of $0.5 \mathrm{~g} / \mathrm{L}$ additional $\mathrm{L}$-proline supply after different time intervals on glycerol consumption and lipid yield. $\mathbf{d}$ Effects of different L-proline levels on lipid production. e Effects of $0.5 \mathrm{~g} / \mathrm{L} \mathrm{L}$-proline addition after different time intervals on lipid production. $\mathbf{f}$ Effects of $0.5 \mathrm{~g} / \mathrm{L}$ additional L-proline supply after different time intervals on lipid production

In fact, L-proline at all tested levels improved overall fermentation efficiency of the strain in terms of glycerol consumption, growth, lipid production and yield. The cell mass of $20.3 \mathrm{~g} / \mathrm{L}$, lipid of $10.1 \mathrm{~g} / \mathrm{L}$ and lipid contents of $49 \%$ were significantly higher $(P<0.001)$ at $0.5 \mathrm{~g} / \mathrm{L}$ L-proline addition than those of 18.4, 6.6 and $35 \%$, respectively, on control. Furthermore, the lipid yield of $0.21 \mathrm{~g} / \mathrm{g}$ was also far higher with $0.5 \mathrm{~g} / \mathrm{L} \mathrm{L}$-proline addition than that of control i.e., $0.15 \mathrm{~g} / \mathrm{g}$. These accounted for $34 \%$ and $28 \%$ increase in lipid and lipid yield, respectively, (Fig. 4d). Likewise, $0.5 \mathrm{~g} / \mathrm{L}$ L-proline addition also improved the glycerol consumption of i.e., $46.7 \mathrm{~g} / \mathrm{L}$ (Fig. 4a). Although there were no substantial differences in lipid contents and yield among all L-proline concentrations used, but the lipid contents of $44 \%$ with glycerol consumption of $41.8 \mathrm{~g} / \mathrm{L}$ were comparatively the lowest with $1.25 \mathrm{~g} / \mathrm{L} \mathrm{L}$-proline addition, indicating that the proline concentration was a bit higher which might affected the yeast efficiency.

To find a suitable L-proline supply time, $100 \mathrm{~g} / \mathrm{L}$ crude glycerol media with $10 \%$ methanol and $\mathrm{K}_{2} \mathrm{SO}_{4}$, respectively, was supplied with $0.5 \mathrm{~g} / \mathrm{L}$ L-proline at different time intervals: initially (GP-Initial), at $24 \mathrm{~h}$ (G-P24), $48 \mathrm{~h}$ (G-P48) and $72 \mathrm{~h}$ (G-P72), respectively (Fig. 4b, e). The control carried no L-proline. After $144 \mathrm{~h}$, significantly higher $(P<0.001)$ cell mass and lipid were achieved with L-proline addition compared with the control. The highest cell mass of $19.7 \mathrm{~g} / \mathrm{L}$ and lipid of $11.6 \mathrm{~g} / \mathrm{L}$ attained at G-P48 followed by G-P24, where these were $19.2 \mathrm{~g} / \mathrm{L}$, $11.3 \mathrm{~g} / \mathrm{L}$, respectively. Moreover, G-P72 was with a bit lower lipid of $10.8 \mathrm{~g} / \mathrm{L}$, which might was due to late L-proline supply, where the yeast took less advantage of L-proline (Fig. 4e). Even though the differences were not substantial with $0.5 \mathrm{~g} / \mathrm{L}$ L-proline addition after different time intervals, but the cell mass and lipid were higher than those of control and GP-Initial. Since, the glycerol consumption and lipid yield reached the highest i.e., $47.3 \mathrm{~g} / \mathrm{L}$ and 25.1, respectively, on G-P48. In contrast, the control was with $44.9 \mathrm{~g} / \mathrm{L}$ glycerol consumption and a lower lipid yield of 20.8 (Fig. 4b).

We further investigated the effects L-proline on lipid accumulation, the same media as above with $0.5 \mathrm{~g} / \mathrm{L}$ initial L-proline contents was additionally supplemented with $0.5 \mathrm{~g} / \mathrm{L} \mathrm{L}$-proline after different time intervals, i.e., $24 \mathrm{~h}$ (GP-24), $48 \mathrm{~h}$ (GP-48), and $72 \mathrm{~h}$ (GP-72). Unlikely, one set was supplied additionally with $0.125 \mathrm{~g} / \mathrm{L} \mathrm{L}$-proline every $24 \mathrm{~h}$ interval for 4 days (GP-Ed). The control had no L-proline, while one set initially supplemented with $0.5 \mathrm{~g} / \mathrm{L} \mathrm{L}$-proline was kept without additional L-proline supply (GP) (Fig. 4f). 
After $144 \mathrm{~h}$, significantly higher $(P<0.001)$ cell mass and lipid were achieved on all L-proline added media compared to those with the control. Although, compared with GP, the cell mass and lipid were higher at all media with additional L-proline supply. Since, GP-Ed was with highest cell mass of $20.4 \mathrm{~g} / \mathrm{L}$ and $12.5 \mathrm{~g} / \mathrm{L}$ lipid which indicated that the readily available L-proline had more encouraging effects on the yeast efficiency. Moreover, GP-24 was also likely with higher cell mass of $19.6 \mathrm{~g} / \mathrm{L}$ and lipid of $12.0 \mathrm{~g} / \mathrm{L}$. On the other hand, the cell mass and lipid were bit lower i.e., $17.2 \mathrm{~g} / \mathrm{L}$ and $11.5 \mathrm{~g} / \mathrm{L}$, respectively, on GP-Initial while the control was with the lowest cell mass of $16.6 \mathrm{~g} / \mathrm{L}$ and lipid of $9.9 \mathrm{~g} / \mathrm{L}$ (Fig. $4 \mathrm{f}$ ). Similarly, the lipid yield reached the highest $0.24 \mathrm{~g} / \mathrm{g}$ with $50.5 \mathrm{~g} / \mathrm{L}$ glycerol consumption on GP-Ed (Fig. 4c). In fact, additional L-proline showed more encouraging effects on the cell growth and lipid accumulation.

All these results demonstrated that exogenous L-proline not only improved the lipid production but also relieved the stress conditions and promoted the cell growth $[45,46]$. Though, the additional L-proline showed more promising effects compared with only initial L-proline supply which indicates low amount of L-proline addition after intervals might be prove more beneficial.

The results of microbial lipid production on crude glycerol by different oleaginous yeasts are summarised in Table 1. Our work demonstrated comparatively improved results in terms of lipid titer and yield, which demonstrated L-proline as a potential anti-stress agent. However, engineering $R$. toruloides for improved L-proline biosynthesis could contribute to biorefinery with enhance lipid titer, yield and short production time by quick resource utilization.

\section{Overview on L-proline metabolism in yeast}

The yeasts cell biosynthesize L-proline in the cytoplasm from glutamate through $\gamma$-glutamyl kinase, $\gamma$-glutamyl phosphate reductase, and $\Delta^{1}$-pyrroline-5-carboxylate reductase produced by the genes PRO1, PRO2 and PRO3, respectively [48, 49]. Moreover, S. cerevisiae additionally biosynthesize L-proline by converting arginine with arginase and ornithine aminotransaminase produced by CAR1 and CAR2 genes, respectively [50]. On the contrary, L-proline is catabolized to glutamate by proline oxidase and $\Delta^{1}$-pyrroline-5-carboxylate dehydrogenase produced by the genes PUT1 and PUT2, respectively, [51]. The L-proline metabolic pathway in yeast is described in Additional file 1: Figure S1).

\section{Fatty acid compositional profiles of the lipid products}

The majority of lipids produced by oleaginous yeasts are triacylglycerols (TAG), which mainly consist of long chain fatty acids including C14:0 (myristic acid), C16:0 (palmitic acid), C18:0 (stearic acid), C18:1 (oleic acid) and C18:2 (linoleic acid). The fatty acid profiles may vary to some extent depending on the culture media and cultivation conditions [57]. The fatty acid methyl esters (FAME) of the transmethylated lipid samples were analysed with GC-FID. Myristic acid, palmitic acid, stearic acid and oleic acid were found in all samples. However, the contents of those with 16 and 18 carbon atoms were above $96 \%$ of the total fatty acids, where palmitic acid accounted for about $50 \%$ followed by oleic acid (Table 2). It is noteworthy that oleaginous yeasts produce lipids with 16 and 18 carbon containing fatty acids as the major fractions [58], which are considered as a potential feedstock for biodiesel industry [59].

\section{Conclusion}

We have illustrated the effects of exogenous L-proline on the red yeast $R$. toruloides lipid production efficiency under crude glycerol stress. L-Proline improved the yeast growth and lipid production on glycerol in the presence of high amount of methanol and salt. Our finding concluded that exogenous L-proline not only improved the cell growth and lipid production by $22 \%$ and $34 \%$, respectively, but also enhanced the lipid yield by $20 \%$ along with higher glycerol consumption. In conclusion, engineering $R$. toruloides for enhanced endogenous L-proline synthesis can aid in fermentation processes with a speedy resource utilization and efficient lipid production under several environmental anxieties.

\section{Materials and methods}

\section{Microorganism, media and growth conditions}

The red yeast strain $R$. toruloides CGMCC 2.1389 was obtained from China General Microbiological Culture Collection Centre. The strain was maintained at $4{ }^{\circ} \mathrm{C}$ on yeast extract-peptone-dextrose (YEPD) agar plate containing $20 \mathrm{~g} / \mathrm{L}$ glucose $\cdot \mathrm{H}_{2} \mathrm{O}, 10 \mathrm{~g} / \mathrm{L}$ peptone, $10 \mathrm{~g} / \mathrm{L}$ yeast extract and $20 \mathrm{~g} / \mathrm{L}$ agar, and sub-cultured twice a month. Peptone (total nitrogen 14.5\% and phosphorus 0.14\%) and yeast extract (total nitrogen 9\% and phosphorus 1.3\%) were obtained from Aoboxing Biotech. Co. Ltd. (Beijing, China). The seed cells were cultured on YEPD medium containing $20 \mathrm{~g} / \mathrm{L}$ glucose $\cdot \mathrm{H}_{2} \mathrm{O}, 10 \mathrm{~g} / \mathrm{L}$ yeast extract, and $10 \mathrm{~g} / \mathrm{L}$ peptone, $\mathrm{pH} 6.0$.

The composition of crude glycerol varies but typically comprises of glycerol (60-90\%), salts (5-6\%) and methanol (4-6\%) [14] [15] [52]. In this work, synthetic crude glycerol stock solution was prepared by dissolving pure glycerol, methanol and $\mathrm{K}_{2} \mathrm{SO}_{4}$, in distilled water to final concentrations of $60 \mathrm{wt} \%, 6 \mathrm{wt} \%$ and $6 \mathrm{wt} \%$, respectively [34]. Therefore, the lipid production media contained (unless otherwise specified) glycerol $50 \mathrm{~g} / \mathrm{L}$, 
methanol $5 \mathrm{~g} / \mathrm{L}, \mathrm{K}_{2} \mathrm{SO}_{4} 5 \mathrm{~g} / \mathrm{L}$, and L-proline $0.5 \mathrm{~g} / \mathrm{L}$, where the control contained no L-proline. The initially set media $\mathrm{pH} 5.5$ with $\mathrm{HCl}$ or $\mathrm{KOH}$ solutions was maintained with $100 \mathrm{mM}$ 2-(N-morpholino)ethanesulfonic acid (MES) buffer. All of the culture media were sterilized at $121{ }^{\circ} \mathrm{C}$ for $20 \mathrm{~min}$. Note that, methanol was supplied to the lipid production media after sterilization (unless otherwise specified).

\section{Seed culture inoculation}

Two-stage culture conditions were employed with a high initial cells density. Shortly, R. toruloides CGMCC 2.1839 cells were inoculated in YEPD media and cultivated at $30{ }^{\circ} \mathrm{C}, 200 \mathrm{rpm}$ for $40 \mathrm{~h}$. Cells from $40 \mathrm{~mL}$ of preculture were then collected at $5000 \mathrm{rpm}$ centrifugation for $5 \mathrm{~min}$, washed twice with deionized water and used as seed for lipid production.

The seed cells at an initial concentration of $7.0 \mathrm{~g} / \mathrm{L}$ were then transferred into $250 \mathrm{~mL}$ flask containing $50 \mathrm{~mL}$ of lipid production media, and incubated at $30{ }^{\circ} \mathrm{C}, 200 \mathrm{rpm}$ for $120 \mathrm{~h}$ (unless otherwise specified). All culture experiments were performed in triplicates.

\section{Analytical methods}

After incubation, cells were harvested at $8000 \mathrm{rpm}$ centrifugation for $5 \mathrm{~min}$, washed twice with deionized water and dried at $105{ }^{\circ} \mathrm{C}$ to constant weight [60]. The cell mass was measured gravimetrically, the cell mass was expressed in $\mathrm{g} / \mathrm{L}$.

To extract lipid, the dried cells were digested with $4 \mathrm{M} \mathrm{HCl}$ solution at $78{ }^{\circ} \mathrm{C}$ for $1 \mathrm{~h}$ at $200 \mathrm{rpm}$ shaking, extracted via methanol/chloroform $(1: 2, \mathrm{v} / \mathrm{v})$. The extracts were washed with $0.1 \% \mathrm{NaCl}$ and passed through anhydrous $\mathrm{Na}_{2} \mathrm{SO}_{4}$ pad, then concentrated under reduced pressure, dried at $105^{\circ} \mathrm{C}$ to constant weight [61], and the lipid was measured gravimetrically. The total produced lipid were expressed in $\mathrm{g} / \mathrm{L}$, the cellular lipid contents in percent (\%) were calculated as gram lipid produced per gram cell mass. The lipid yield was defined as gram lipid produced per gram glycerol consumed (g/g glycerol consumed).

The fatty acids compositional profile of the transesterified lipid samples were analysed with gas chromatography (GC) according to a previous work [62]. Briefly, the lipid sample $(70 \mathrm{mg})$ was treated with $0.5 \mathrm{~mL}$ of $5 \% \mathrm{KOH}$ methanol at $65{ }^{\circ} \mathrm{C}$ for $50 \mathrm{~min}$, then $0.2 \mathrm{~mL}$ $\mathrm{BF}_{3}$ diethyletherate and $0.5 \mathrm{~mL}$ methanol were added. The mixture was refluxed for $10 \mathrm{~min}$, cooled, and extracted with $\mathrm{n}$-hexane. The organic layer was washed twice with distilled water and used for fatty acid compositional analysis. Then, the compositional profiling of fatty acid was measured by a 7890F GC (Techcomp
Scientific Instrument Co. Ltd., Shanghai, China), which was equipped with a cross-linked capillary FFAP column $(30 \mathrm{~m} \times 0.25 \mathrm{~mm} \times 0.25 \mathrm{~mm})$ and a flame ionization detector. The flow rates for $\mathrm{N}_{2}, \mathrm{H}_{2}$, and air were $720 \mathrm{~mL} / \mathrm{min}, 30 \mathrm{~mL} / \mathrm{min}$, and $100 \mathrm{~mL} / \mathrm{min}$, respectively. The injection port, oven, and detector temperature were set at $250{ }^{\circ} \mathrm{C}, 190{ }^{\circ} \mathrm{C}$ and $280{ }^{\circ} \mathrm{C}$, respectively. The injection volume was $0.5 \mu \mathrm{L}$. Fatty acids were identified and quantified by comparing the retention time of those with standards and the respective peak areas and area normalization.

L-proline and glycerol analysis were performed with ion chromatography (IC) by using an ICS-5000 series instrument (Thermo-Fisher Scientific Waltham, MA, USA). The AminoPac PA10 column set consisting of a guard column $(4 \mathrm{~mm} \times 50 \mathrm{~mm})$ and an analytical column $(4 \mathrm{~mm} \times 250 \mathrm{~mm})$. Gradient elution was performed at a flow-rate of $0.25 \mathrm{~mL} / \mathrm{min}$, with water, sodium hydroxide, and sodium acetate mobile phases using the ternary gradient method. The temperature of the column was maintained at $30{ }^{\circ} \mathrm{C}$. Results were quantified according to the L-proline and glycerol standard chromatogram. Additionally, glycerol was also quantified with a previously established spectrophotometric procedure by combining the Malaprade reaction and the Hantzsch reaction [63].

\section{Statistical analysis}

The jamovi project (2020) jamovi (Version 1.2) [Computer Software] was used for statistical analysis. One-way ANOVA was conducted to compare control group with L-proline added group. Data with $p<0.05$ was considered statistically significant.

\section{Supplementary information}

Supplementary information accompanies this paper at https://doi. org/10.1186/s13068-020-01798-6.

Additional file 1: Figure S1. L-proline metabolic pathway in yeast.

\section{Abbreviations}

CGMCC: China General Microbiological Culture Collection Centre; YEPD: Yeast extract-peptone-dextrose; MES: 2-(N-morpholino)ethanesulfonic acid; GC: Gas chromatography; IC: Ion chromatography; $\mathrm{HCl}$ : Hydrochloric acid; $\mathrm{KOH}$ : Potassium hydroxide; FAMEs: Fatty acid methyl esters.

\section{Acknowledgements}

Not applicable.

\section{Authors' contributions}

ZKZ and RK conceived the project and designed the experiments. RK performed the experiments. RK and WQ did Ion Chromatography analysis. RK, LYX, LQ, YX and HQT discussed the results. RK and ZKZ wrote and revised the manuscript. All authors read and approved the final manuscript.

\section{Funding}

This work was financially supported by National Natural Science Foundation of China (Nos. 51761145014 and 21721004). 


\section{Availability of data and materials}

Additional file 1 contains supporting information

\section{Ethics approval and consent to participate}

Not applicable.

\section{Consent for publication}

All the authors agreed for publication.

\section{Competing interests}

The authors declare no competing interests.

\section{Author details}

${ }^{1}$ Laboratory of Biotechnology, Dalian Institute of Chemical Physics, CAS, 457 Zhongshan Road, Dalian 116023, People's Republic of China. ${ }^{2}$ Dalian Key Laboratory of Energy Biotechnology, Dalian Institute of Chemical Physics, CAS, 457 Zhongshan Road, Dalian 116023, People's Republic of China. ${ }^{3}$ University of Chinese Academy of Sciences, Beijing 100049, People's Republic of China.

\section{Received: 2 May 2020 Accepted: 4 September 2020}

\section{Published online: 14 September 2020}

\section{References}

1. Yang F, Hanna MA, Sun R. Value-added uses for crude glycerol-a byproduct of biodiesel production. Biotechnol Biofuels. 2012;5:13.

2. Du W, Kamal R, Zhao ZK. Biodiesel. Compr Biotechnol 3rd Ed. Elsevier: Pergamon. 2019; pp. 66-78

3. Antolın G, Tinaut FV, Briceno Y, Castano V, Perez C, Ramırez Al. Optimisation of biodiesel production by sunflower oil transesterification. Bioresour Technol. 2002;83:111-4.

4. Anand P, Saxena RK. A comparative study of solvent-assisted pretreatment of biodiesel derived crude glycerol on growth and 1,3-propanediol production from Citrobacter freundii. N Biotechnol. 2012;29:199-205

5. Mu Y, Xiu ZL, Zhang DJ. A combined bioprocess of biodiesel production by lipase with microbial production of 1,3-propanediol by Klebsiella pneumoniae. Biochem Eng J. 2008;40:537-41.

6. Wahlen BD, Morgan MR, McCurdy AT, Willis RM, Morgan MD, Dye DJ, Bugbee B, Wood BD, Seefeldt LC. Biodiesel from microalgae, yeast, and bacteria: Engine performance and exhaust emissions. Energ Fuel. 2013;27:220-8

7. Ochsenreither K, Glück C, Stressler T, Fischer L, Syldatk C. Production strategies and applications of microbial single cell oils. Front Microbiol. 2016:7:1-26.

8. Li Q, Du W, Liu D. Perspectives of microbial oils for biodiesel production. Appl Microbiol Biotechnol. 2008;749-56.

9. Kumar D, Singh B, Korstad J. Utilization of lignocellulosic biomass by oleaginous yeast and bacteria for production of biodiesel and renewable diesel. Renew Sustain Energy Rev. 2017;73:654-71.

10. Li Q, Kamal R, Wang Q, Yu X, Zhao ZK. Lipid production from amino acid wastes by the oleaginous yeast Rhodosporidium toruloides. Energies. 2020;13:1576

11. Dourou M, Kancelista A, Juszczyk P, Sarris D, Bellou S, Triantaphyllidou IE, Rywinska A, Papanikolaou S, Aggelis G. Bioconversion of olive mill wastewater into high-added value products. J Clean Prod. 2016;139:957-69.

12. Liao JC, Mi L, Pontrelli S, Luo S. Fuelling the future: microbial engineering for the production of sustainable biofuels. Nat Rev Microbiol. 2016;14:288-304

13. Huang C, Chen XF, Xiong L, Ma LL, Chen Y. Single cell oil production from low-cost substrates: the possibility and potential of its industrialization. Biotechnol Adv. 2013;31:129-39.

14. Papanikolaou S, Fakas S, Fick M, Chevalot I, Galiotou-Panayotou M, Komaitis M, Marc I, Aggelis G. Biotechnological valorisation of raw glycerol discharged after biodiesel (fatty acid methyl esters) manufacturing process: production of 1,3-propanediol, citric acid and single cell oil. Biomass Bioenerg. 2008;32:60-71.
15. Ashby RD, Solaiman DK, Strahan GD. Efficient utilization of crude glycerol as fermentation substrate in the synthesis of poly(3-hydroxybutyrate) biopolymers. J Am Oil Chem Soc. 2011;88:949-59.

16. Chatzifragkou A, Papanikolaou S, Dietz D, Doulgeraki Al, Nychas GJ, Zeng AP. Production of 1,3-propanediol by Clostridium butyricum growing on biodiesel-derived crude glycerol through a non-sterilized fermentation process. Appl Microbiol Biotechnol. 2011;91:101-12.

17. Zhang X, Shanmugam KT, Ingram LO. Fermentation of glycerol to succinate by metabolically engineered strains of Escherichia coli. Appl Environ Microbiol. 2010;76:2397-401.

18. Kitcha S, Cheirsilp B. Enhancing lipid production from crude glycerol by newly isolated oleaginous yeasts: strain selection, process optimization, and fed-batch strategy. Bioenergy Res. 2013;6:300-10.

19. Rahim A, Hafiz M, Hasan H, Lim EJ, Samrani PK, Abbas A. Pretreatment strategies to improve crude glycerol utilisation and metabolite production by Aspergillus terreus. Int J Chem Eng. 2019;2019:1-6.

20. Wijesekara RGS, Nomura N, Sato S, Matsumura M. Pre-treatment and utilization of raw glycerol from sunflower oil biodiesel for growth and 1 , 3-propanediol production by Clostridium butyricum. J Chem Technol Biotechnol. 2008;83(7):1072-80.

21. Takagi $H$. Proline as a stress protectant in yeast: Physiological functions, metabolic regulations, and biotechnological applications. Appl Microbiol Biotechnol. 2008;211-23.

22. Rudolph AS, Crowe JH. Membrane stabilization during freezing: the role of two natural cryoprotectants, trehalose and proline. Cryobiology. 1985;22:367-77.

23. Hayat S, Hayat Q, Alyemeni MN, Wani AS, Pichtel J, Ahmad A. Role of proline under changing environments: a review. Plant Signal Behav. 2012;7:1456-66.

24. Rajendrakumar CS, Suryanarayana T, Reddy AR. DNA helix destabilization by proline and betaine: possible role in the salinity tolerance process. FEBS Lett. 1997;410:201-5.

25. Schobert B, Tschesche H. Unusual solution properties of proline and its interaction with proteins. Biochim Biophys Acta. 1977;541:270-7.

26. Ignatova $Z$, Gierasch LM. Inhibition of protein aggregation in vitro and in vivo by a natural osmoprotectant. Proc Natl Acad Sci USA. 2006;103:13357-61.

27. Mohanty P, Matysik J. Effect of proline on the production of singlet oxygen. Amin Acid. 2001;21:195-200.

28. Kaul S, Sharma SS, Mehta IK. Free radical scavenging potential of L-proline: evidence from in vitro assays. Amino Acid. 2008;2:315-20.

29. Chen C, Dickman MB. Proline suppresses apoptosis in the fungal pathogen Colletotrichum trifolii. Proc Natl Acad Sci USA. 2005;102:3459-64.

30. Krishnan N, Dickman MB, Becker DF. Proline modulates the intracellular redox environment and protects mammalian cells against oxidative stress. Free Radical Bio Med. 2008:44:671-81.

31. Liang Y, Cui Y, Trushenski J, Blackburn JW. Converting crude glycerol derived from yellow grease to lipids through yeast fermentation. Bioresour Technol. 2010;101:7581-6.

32. Li YH, Liu B, Zhao ZB, Bai FW. Optimization of culture conditions for lipid production by Rhodosporidium toruloides. Chin J Biotechnol. 2006;22:650-6

33. Chatzifragkou A, Makri A, Belka A, Bellou S, Mavrou M, Mastoridou M, Mystrioti P, Onjaro G, Aggelis G, Papanikolaou S. Biotechnological conversions of biodiesel derived waste glycerol by yeast and fungal species. Energy. 2011;36:1097-108.

34. Yang X, Jin G, Gong Z, Shen H, Bai F, Zhao ZK. Recycling biodiesel-derived glycerol by the oleaginous yeast Rhodosporidium toruloides $Y 4$ through the two-stage lipid production process. Biochem Eng J. 2014;91:86-91.

35. Gao Z, Ma Y, Wang Q, Zhang M, Wang J, Liu Y. Effect of crude glycerol impurities on lipid preparation by Rhodosporidium toruloides yeast 32489 . Bioresour Technol. 2016;218:373-9.

36. Chen BJ, Lim HC, Tsao GT. A model for bacterial growth on methanol. Biotechnol. Bioeng. 1976. p. 1629-33.

37. Pyle DJ, Garcia RA, Wen Z. Producing docosahexaenoic acid (DHA)-rich algae from biodiesel-derived crude glycerol: effects of impurities on DHA production and algal biomass composition. J Agric Food Chem. 2008;56:3933-9. 
38. Chen J, Zhang X, Yan S, Dayal R, Drogui P. Lipid production from fed-batch fermentation of crude glycerol directed by the kinetic study of batch fermentations. Fuel. 2017;209:1-9.

39. Chen J, Zhang X, Dayal R, Drogui P. Utilization of methanol in crude glycerol to assist lipid production in non-sterilized fermentation from Trichosporon oleaginosus. Bioresour Technol. 2018;253:8-15.

40. Liu LP, Zong MH, Hu Y, Li N, Lou WY, Wu H. Efficient microbial oil production on crude glycerol by Lipomyces starkeyi AS 2.1560 and its kinetics. Process Biochem. 2017:58:230-8.

41. Swartz JR, Cooney CL. Methanol inhibition in continuous culture of Hansenula polymorpha. Appl Environ Microbiol. 1981;41:1206-13.

42. Uprety BK, Dalli SS, Rakshit SK. Bioconversion of crude glycerol to microbial lipid using a robust oleaginous yeast Rhodosporidium toruloides ATCC 10788 capable of growing in the presence of impurities. Energy Convers Manag. 2017;135:117-28.

43. Gu N, Lin Q, Li G, Tan Y, Huang L, Lin J. Effect of salinity on growth, biochemical composition, and lipid productivity of Nannochloropsis oculata CS 179. Eng Life Sci. 2012;12:631-7.

44. Venkataramanan KP, Boatman JJ, Kurniawan Y, Taconi KA, Bothun GD, Scholz C. Impact of impurities in biodiesel-derived crude glycerol on the fermentation by Clostridium pasteurianum ATCC 6013. Appl Microbiol Biotechnol. 2012;93:1325-35.

45. Wang X, Bai X, Chen DF, Chen FZ, Li BZ, Yuan YJ. Increasing proline and myo-inositol improves tolerance of Saccharomyces cerevisiae to the mixture of multiple lignocellulose-derived inhibitors. Biotechnol Biofuels. 2015:8:1-13.

46. Liao Z, Guo X, Hu J, Suo Y, Fu H, Wang J. The significance of proline on lignocellulose-derived inhibitors tolerance in Clostridium acetobutylicum ATCC 824. Bioresour Technol. 2019:272:561-9.

47. Morita Y, Nakamori S, Takagi H. Effect of proline and arginine metabolism on freezing stress of Saccharomyces cerevisiae. J Biosci Bioeng. 2002;94:390-4.

48. Brandriss MC, Falvey DA. Proline biosynthesis in Saccharomyces cerevisiae: analysis of the PRO3 gene, which encodes $\triangle 1$-pyrroline-5-carboxylate reductase. J Bacteriol. 1992;174:5176.

49. Tomenchok DM, Brandriss MC. Gene-enzyme relationships in the proline biosynthetic pathway of Saccharomyces cerevisiae. J Bacteriol. 1987:169:5364-72.

50. Middelhoven WJ. The pathway of arginine breakdown in Saccharomyces cerevisiae. Biochem Biophys Acta. 1965;31:222-3.

51. Brandriss MC. Proline utilization in Saccharomyces cerevisiae: analysis of the cloned PUT1 gene. Mol Cell Biol. 1983;3:1846-56.
52. Xu J, Zhao X, Wang W, Du W, Liu D. Microbial conversion of biodiesel byproduct glycerol to triacylglycerols by oleaginous yeast Rhodosporidium toruloides and the individual effect of some impurities on lipid production. Biochem Eng J. 2012;65:30-6.

53. Saenge C, Cheirsilp B, Suksaroge TT, Bourtoom T. Potential use of oleaginous red yeast Rhodotorula glutinis for the bioconversion of crude glycerol from biodiesel plant to lipids and carotenoids. Process Biochem. 2011;46:210-8

54. Liu L ping, Hu Y, Lou W yong, Li N, Wu H, Zong M hua. Use of crude glycerol as sole carbon source for microbial lipid production by oleaginous yeasts. Appl Biochem Biotechnol. 2017;182:495-510.

55. Tchakouteu SS, Kalantzi O, Gardeli C, Koutinas AA, Aggelis G, Papanikolaou S. Lipid production by yeasts growing on biodiesel-derived crude glycerol: strain selection and impact of substrate concentration on the fermentation efficiency. J Appl Microbiol. 2015;118:911-27.

56. Xu J, Zhao X, Du W, Liu D. Bioconversion of glycerol into lipids by Rhodosporidium toruloides in a two-stage process and characterization of lipid properties. Eng Life Sci. 2016:3:303-13.

57. Papanikolaou S, Aggelis G. Lipids of oleaginous yeasts. Part I: Biochemistry of single cell oil production. Eur J Lipid Sci Tech. 2011;113:1031-51.

58. Patel A, Arora N, Sartaj K, Pruthi V, Pruthi PA. Sustainable biodiesel production from oleaginous yeasts utilizing hydrolysates of various non-edible lignocellulosic biomasses. Renew Sustain Energy Rev. 2016;62:836-55.

59. Liu B, Zhao ZK. Biodiesel production by direct methanolysis of oleaginous microbial biomass. J Chem Technol Biotechnol. 2007;82:1115-21.

60. Gong Z, Zhou W, Shen H, Yang Z, Wang G, Zuo Z, Hou Y, Zhao ZK. Cofermentation of acetate and sugars facilitating microbial lipid production on acetate-rich biomass hydrolysates. Bioresour Technol. 2016;207:102-8.

61. Wu S, Zhao X, Shen H, Wang Q, Zhao ZK. Microbial lipid production by Rhodosporidium toruloides under sulfate-limited conditions. Bioresour Technol. 2011:102:1803-7.

62. Li Y, Zhao ZK, Bai F. High-density cultivation of oleaginous yeast Rhodosporidium toruloides $Y 4$ in fed-batch culture. Enzyme Microb Technol. 2007:41:312-7.

63. Kuhn J, Müller H, Salzig D, Czermak P. A rapid method for an offline glycerol determination during microbial fermentation. Electron J Biotechnol. 2015;18:252-5

\section{Publisher's Note}

Springer Nature remains neutral with regard to jurisdictional claims in published maps and institutional affiliations.
Ready to submit your research? Choose BMC and benefit from:

- fast, convenient online submission

- thorough peer review by experienced researchers in your field

- rapid publication on acceptance

- support for research data, including large and complex data types

- gold Open Access which fosters wider collaboration and increased citations

- maximum visibility for your research: over 100M website views per year

At BMC, research is always in progress.

Learn more biomedcentral.com/submissions 